Asia Pacific Journals

\title{
A STUDY ON MARKETING INITIATIVES ADOPTED BY ENGINEERING COLLEGES ACROSS
}

BANGALORE DISTRICT

\begin{tabular}{|c|c|}
\hline Ms. Chaithra C & Prof. Raghavendran V \\
MBA Research Scholar, Alva's Institute of Engineering & Assistant Professor, MBA Department, Alva's Institute \\
and Technology, Mijar & of Engineering and Technology, Mijar. \\
Email: chaitracgowda93@gmail.com & Email: aietmbaprofessor@gmail.com \\
\hline
\end{tabular}

\begin{abstract}
The purpose of technical education is to ensure that we have a skilled workforce and engaged to keep our nation, economy, communities, and families healthy and productive. But students need other skills, too. They need to be marketing initiatives to project their colleges for talent hunt is very essential in the 21 st Century.

Career and technical education is an integral part of secondary and post secondary public education and is designed to educate about, through, and for careers. It also prepares colleges for the world of work by introducing them to workplace competencies that are essential no matter what career they choose. And, career technical education takes academic content and makes it accessible to students by providing it in a hands-on context. This study will be conducted by questionnaire method with a sample size of 100 administrators in engineering colleges.
\end{abstract}

Key words: Technical education, Marketing initiatives, promotional strategies, advertisements and Bangalore city.

\section{LITERATURE REVIEW}

Many researchers have discussed the influence of guidance counselors on students' decisions regarding their major prior entering the technical colleges, and a recent study indicates that the counselors themselves lack knowledge about the computing fields and the related job market. Moreover, they don't have sufficient time to inform students about the opportunities available in computing (Saunders \& Hunsinger, 2008). Since guidance counselors might have a great impact on these students, it is well worth talking to them about the computing fields and the job prospects for computing graduates, and the need to set aside sufficient time to discuss a future in computing with these students before they enter the college and decide on a major.

Other positive contributions have been made by students at Carnegie Mellon University, their first initiative generating an outreach presentation that answers two main questions: "Who can be a computer scientist?" and "What can you do with a computer science degree?" Their second 
initiative is a weekly series of technology skills workshops, called "Creative Technology Nights for Girls." These initiatives are planned and presented by female students and cover a range of topics, such as Web page design and building a website, computer illustration, programming, 2-D animation, robot design and robot programming, Internet safety, virtual world construction, programming through visual storytelling, and using Photoshop and Illustrator, as well as social events like Movie Nights, Open Houses, etc. In this way, they challenge stereotypes and promote new images for computer science and its related disciplines (Frieze \& Treat, 2006). It is also worth noting that Stanford University has put in place strategies over the past ten years designed to increase the enrollment of female students in computer science at the undergraduate level. The principal components of that effort are as follows: 1) redesign the introductory sequence to make it accessible to a much wider audience; 2) provide role models for undergraduate women at every stage of the educational process; 3) establish bridge programs for female students, and also minorities, who are at greater risk of leaving the technical fields; and 4) establish a program to engage undergraduates in faculty research (Roberts, Kassianidou, \& Irani, 2003).

\section{NEED OF THE STUDY}

The study was essential to know the marketing attempts made by the technical colleges to attract the prospects, this is due large amount of engineering colleges have opened gates in the almost saturated market.

\section{RESEARCH GAP}

Demand for the engineering course stated declining and the possibility of picking the pace is more, as new colleges are flooding in the markets. This allows the researchers to know; how the technical colleges attract the prospects and what are various techniques imbued to do it is likely be gap for the research.

\section{OBJECTIVE}

The main objective of the study to understand the marketing initiatives carried out by the technical colleges across the Bangalore district.

\section{LIMITATIONS}

- Time constraint was the foremost limiting factor that occurred during the process of conduction of this study. 
- Sample size of survey does not represent the entire colleges of Bangalore district.

- The respondents were hesitant in providing information.

- The response to the questionnaire may or may not be true.

- The busy time schedule of the respondents interrupted them, and prevented discussion.

\section{RESEARCH METHODOLOGY}

Research methodology is a way to systematically solve the research problem. It may be understood as a science of studying how research is done scientifically. It is a process which constitutes the depth of the subject. Research methodology constitutes the base and structure through which data is collected and interpreted. Primary data: Primary data's are the first hand data's, which are directly collected by questionnaire method and observation method also. Secondary data: Secondary data is a data which is already collected by someone for some purpose, may be through referring the books and records given by the firm and also downloaded information from internet. The sample contains 50 institutional representatives; simple random sampling techniques were imbued for the study.

\section{ANALYSIS AND INTERPRETATION}

From the study, it was found that majority being male respondents represented behalf of their institutes and contrary being female respondents. The majority of respondent's designations were principals followed by the employees of the college, administrative officer, management representatives and least being the registrar. Majority of technical colleges across the Bangalore district are unaided and dissimilar are aided colleges, which enjoys grants from government bodies. In the categorization of colleges, it was found that mainstream of the colleges are private, followed by government and least being the autonomous colleges; amongst those greater part of them are affiliated to the university and least being autonomous institute. It was learnt that majority of the institutes offer Master programme and very few offer research programmes too. The colleges were established category; it was found that majority respondents said belongs to $05-08$ years category, trailed by 01-04 years, 1316years, 09-12 years, more than 20 years and 17-20 years. Almost all colleges offer 4 specializations few more than five specializations. 
Table suggests the top scorers in each category and rank based with their points. From the below table it could be said that data, brand, website are highest priority trailed by marketing channels, messages , tactics, marketing, creative approaches, offers and least being the collaterals and sales tools.

\begin{tabular}{|c|l|c|}
\hline \multicolumn{3}{|c|}{ TABLE 12 :THE TOP RANKERS IN } \\
EACH CATEGORY \\
\hline CATEGORY & \multicolumn{1}{|c|}{ STATEMENTS } & P \\
\hline Data & $\begin{array}{l}\text { Are you capturing } \\
\text { customer and } \\
\text { prospect data to build } \\
\text { a robust marketing } \\
\text { database? }\end{array}$ & $\mathbf{2 2 6}$ \\
\hline \multirow{6}{*}{ Brand } & $\begin{array}{l}\text { Does your brand } \\
\text { clearly communicate } \\
\text { what you are about } \\
\text { and convey the } \\
\text { highest value you } \\
\text { deliver? }\end{array}$ & $\mathbf{2 2 4}$ \\
\hline Mebsite & $\begin{array}{l}\text { Is your site fully } \\
\text { optimized for search } \\
\text { engines? }\end{array}$ & $\mathbf{2 1 8}$ \\
\hline \multirow{6}{*}{ Charketing } & $\begin{array}{l}\text { Are you maximizing } \\
\text { the value of the } \\
\text { proprietary channels } \\
\text { you control, such as } \\
\text { newsletters, invoices, } \\
\text { product packaging } \\
\text { and inserts, vehicles, } \\
\text { and buildings? }\end{array}$ & $\mathbf{2 1 7}$ \\
\hline Messages & $\begin{array}{l}\text { Do you have three to } \\
\text { five key marketing } \\
\text { messages that you're } \\
\text { consistently } \\
\text { delivering in all }\end{array}$ & $\mathbf{2 1 6}$ \\
\hline
\end{tabular}

\begin{tabular}{|c|c|c|}
\hline & & \\
\hline $\begin{array}{l}\text { Marketing } \\
\text { Tactics }\end{array}$ & $\begin{array}{l}\text { Are you integrating } \\
\text { social media into } \\
\text { traditional marketing } \\
\text { tactics like direct } \\
\text { mail and advertising? }\end{array}$ & 213 \\
\hline Marketing & $\begin{array}{l}\text { Do you know your } \\
\text { most } \\
\text { customers and are } \\
\text { your } \\
\text { prospects that look } \\
\text { just like your best } \\
\text { customers? }\end{array}$ & 212 \\
\hline $\begin{array}{c}\text { Creative } \\
\text { Approaches }\end{array}$ & $\begin{array}{l}\text { Does your creative } \\
\text { engage the prospect } \\
\text { immediately in your } \\
\text { sales message and } \\
\text { enhance the delivery } \\
\text { of the message? }\end{array}$ & 201 \\
\hline Offers & $\begin{array}{ll}\begin{array}{l}\text { Does your } \\
\text { showcase }\end{array} & \text { offer } \\
\text { product? } & \text { your } \\
\end{array}$ & 201 \\
\hline \multirow[t]{2}{*}{$\begin{array}{c}\text { Collateral } \\
\text { and sales tools }\end{array}$} & $\begin{array}{lr}\text { Are your } & \text { sales } \\
\text { brochures, displays, } & \text { sales } \\
\text { and } & \text { demonstration tools } \\
\text { accurate, complete, } & \text { and up to date? } \\
\end{array}$ & 197 \\
\hline & $\begin{array}{l}\text { Do you need new } \\
\text { tools to educate } \\
\text { prospects about your } \\
\text { industry or product? }\end{array}$ & 197 \\
\hline
\end{tabular}

\section{FINDINGS}

From the above study, the researchers found that the following; majority being male respondents represented behalf of their institutes, majority of respondent's designations were principals, majority of technical colleges across the Bangalore 
district are unaided. In the categorization of colleges, it was found that mainstream of the colleges are private, followed by government and least being the autonomous colleges; amongst those greater part of them are affiliated to the university and least being autonomous institute, it was learnt that majority of the institutes offer Master programme and very few offer research programmes too. The colleges were established category; it was found that majority respondents said belongs to $05-08$ years category and almost all colleges offer 4 specializations few more than five specializations.

From the marketing awareness techniques imbued by the institutes the top five are through radio and TV advertising with 240 points, followed by Print Advertising, Indoor posters, Bill boards with 239 points, Brochures and Pamphlets with 232, Internet advertisement, E-mail Marketing with 227 points and lastly College magazines with 223 points.

In the each category of marketing elements in Higher education, it was found that in ranking order that Data category with a statement "Are you capturing customer and prospect data to build a robust marketing database?" with 226 points, trailed by Brand category "Does your brand clearly communicate what you are about and convey the highest value you deliver?" with 224 points, Website category "Is your site fully optimized for search engines" with 218 points, Marketing Channels category "Are you maximizing the value of the proprietary channels you control, such as newsletters, invoices, product packaging and inserts, vehicles, and buildings?" with 217 points, Messages category "Do you have three to five key marketing messages that you're consistently delivering in all media?" with 216 points, Marketing Tactics category "Are you integrating social media into traditional marketing tactics like direct mail and advertising?" with 213 points, Marketing category "Do you know your most profitable customers and are your targeting prospects that look just like your best customers?" with 212 points, Creative Approaches category "Does your creative engage the prospect immediately in your sales message and enhance the delivery of the message?" with 201 points, Offers category "Does your offer showcase your product?" with 201 points and last category of Collateral and sales tools two 
statements "Are your sales brochures, displays, and sales demonstration tools accurate, complete, and up to date?' and "Do you need new tools to educate prospects about your industry or product?" have 197 points.

\section{SUGGESTIONS}

AND

\section{RECOMMENDATIONS}

Although the proposed study on a study on marketing initiatives adopted by engineering colleges across Bangalore district shows promising results, the researchers have added a set of suggestions in this section to improve it even more. This study should be extended as a sustainable marketing plan to engineering and other, since activities and events shaped up the colleges are uniform and orthodox I nature, a committee must be formed to market the technical education in college level. The committee should meet at least monthly and report to the designated authorities. From the study it was found that regular marketing practices are taken place, the various e marketing tools and techniques are available and largest platform available is social media websites. Majority are concerned about the data and prospects for their respective colleges, the data clcan be enriched using various marketing tools such as Audio Conferencing, Video Conferencing, Tele Text, DBS (Direct broadcasting satellites) and On Screen Cinema.

If everyone of the college work force contributes a little time and effort, to a great deal. Such marketing contributions can be made part of the annual faculty evaluation under services, in this case to the technical college i.e. every faculty member records what he or she did to contribute to the enrollment of students at the College.

\section{CONCLUSION}

The aim of India 2020 is to ensure that India has one of the top five educational hub in the world by 2020. Higher Education plays a vital role in running economy of one's country, and technical Colleges of IT capital of India is doing its best to attract more students to this field and help the objectives of India Vision 2020 to be met. In this paper, we introduced the technical College of marketing strategy, which primarily aims know the techniques imbued by each technical colleges across Bangalore city. There are lot opportunities from the study to improve upon the quality of Marketing and intake of the students. Further this study allows indexing the technical colleges with 
ELK

Asia Pacific Journals

marketing and student's performance and gap will be minimized by adopting quality performance. Finally, we presented our suggestions and recommendations for the proposed marketing strategy.

\section{REFERENCES}

[1] Abu Talib, M., \& El Barachi, M. (2011). Revitalizing the IT college: A case study. In Proceedings of the 2nd Conference on Technology Management (MCTM - 2011). Dubai, UAE.

[2] ADW. (2010, September 22). Abu Dhabi Vision 2030 -- Looking to the future. Retrieved September 15, 2011, from Abu Dhabi Week Carter, L. (2006).

[3] Why students with an apparent aptitude for computer science don't choose to major in computer science. Proceedings of the 37th SIGCSE Technical Symposium on Computer Science Education (SIGCSE '06). Houston, Texas, USA.

[4] CSTA. (2003). A model curriculum for K-12 computer science: Final report of the ACM K-12 Task Force. USA: ACM.

[5] Fisher, A., Margolis, J., \& Miller, F. (1997). Undergraduate women in computer science: Experience, motivation and culture. Proceedings of
ELK Asia Pacific Journals - Special Issue ISBN: 978-81-930411-5-4

the 28th SIGCSE Technical Symposium on Computer Science Education (SIGCSE 1997). San Jose, CA, USA.

[6] Force, I. D. (2008). IST strategic plan: Building the brand through partnership networks for excellence. University Park.

[7] Frieze, C., \& Treat, E. (2006). Diversifying the images of computer science: Carnegie Mellon students take on the challenge! USA: Proceedings of Women in Engineering Programs and Advocates Network

(WEPAN)

Conference.

[8] Guzdial, M., \& Forte, A. (2005). Design process for a non-majors computing course. Proceedings of the 36th SIGCSE Technical Symposium on Computer Science Education (SIGCSE'05). St. Louis, Missouri, USA.

[9] Masdar. (2011). The Abu Dhabi Economic Vision 2030. Retrieved September 15, 2011, from The Government of Abu Dhabi http://www.masdarcity.ae/userfiles/files/ economic-vision-2030-executivesummary-mandate 2 .pdf

[10] Roberts, E. S., Kassianidou, M., \& Irani, L. (2003). Encouraging women in computer science. Stanford, CA. 